\title{
YIELD OF BORO RICE UNDER SYSTEM OF RICE INTENSIFICATION WITH DIFFERENT WATER REGIMES AND MANURAL STATUS
}

\author{
M. J. Rahman' 1 , P. K. Biswas' ${ }^{2}$, A. K. M. R. Amin ${ }^{2}$ and A. Zahan ${ }^{3}$ \\ ${ }^{1}$ Agronomist, BRAC Agriculture Research and Development Centre (BARDC), Gazipur, ${ }^{2}$ Professor, Department of \\ Agronomy, SAU, ${ }^{3}$ Senior Sector Specialist, BRAC Education Program (BEP), Mohakhali, Dhaka. \\ Corresponding author: julfiker.rahman@brac.net
}

Key words: water regime, manural status, yield performance, SRI

\begin{abstract}
A field experiment was carried out at the Agronomy Field, Sher-e-Bangla Agricultural University, Dhaka from December, 2011 to May, 2012 to study the yield of Boro rice under system of rice intensification (SRI) with different water regimes and manural status. The experiment consisted of two factors as three water regime viz., waterlogged condition $\left(\mathrm{W}_{1}\right)$, saturated condition $\left(\mathrm{W}_{2}\right)$ and alternate wet and dry condition $\left(\mathrm{W}_{3}\right)$ in the main plots, and six manure and fertilizer combinations viz., cowdung $100 \%\left(\mathrm{~F}_{1}\right)$, compost $100 \%\left(\mathrm{~F}_{2}\right)$, chemical fertilizer $100 \%\left(\mathrm{~F}_{3}\right), 50 \%$ chemical fertilizer $+25 \%$ compost $+25 \%$ cowdung $\left(\mathrm{F}_{4}\right), 50 \%$ chemical fertilizer $+50 \%$ cowdung $\left(\mathrm{F}_{5}\right)$ and $50 \%$ chemical fertilizer + $50 \%$ compost $\left(\mathrm{F}_{6}\right)$ in the sub-plots. Water regime had significant effect on yield and yield components except number of effective tillers $\mathrm{m}^{-2}$, filled grains panicle $e^{-1}$, weight of 1000grain and harvest index. The highest grain yield $\left(5.74 \mathrm{t} \mathrm{ha}^{-1}\right)$ was obtained from the waterlogged condition that was statistically similar with saturated condition (5.69), whereas alternate wet and dry (AWD) gave the lowest grain yield $\left(4.36 \mathrm{tha}^{-1}\right)$. Manural status also significantly influenced yield attributes except 1000-grains weight. The combination of chemical fertilizer, cowdung and compost showed the best performance compared to other manural status. The highest grain yield $\left(5.81 \mathrm{t} \mathrm{ha}^{-1}\right)$ was obtained from chemical fertilizer 50\% + cowdung $25 \%+$ compost $25 \%$ and the lowest grain yield $\left(4.71 \mathrm{t} \mathrm{ha}^{-1}\right)$ was obtained from compost $100 \%$. The highest number of effective tillers hilll $^{-1}$ (33.71) was obtained from compost 100\%. Chemical fertilizer 50\% + cowdung $25 \%+$ compost $25 \%$ showed the highest harvest index (46.78\%). In case of interaction effect of water regime and manural status the highest grain yield was observed in chemical fertilizer $50 \%+$ cowdung $25 \%+$ compost $25 \%$ of saturated condition $(6.80 \mathrm{t}$ ha-1).
\end{abstract}

\section{Introduction}

Rice is the foremost staple food for more than $50 \%$ of the world's population (Thakur et al., 2011). There is an upward shift in demand for rice worldwide due to population increase and urbanization, as people change their food habits (Mishra, 2009), leading to high shelf prices. Between 2006 and 2008, average world prices for rice grew by 217\%, compared to wheat which increased by $136 \%$, corn by $125 \%$, and soybeans by $107 \%$ (FAO, 2010). About $75 \%$ of the total cropped area and more than $80 \%$ of the total irrigated area is planted to rice in Bangladesh (Hossain and Deb, 2003). Almost all of the 13 million farm families grow rice. It provides nearly $40 \%$ of national employment (48\% of rural employment), about $70-76 \%$ of total calorie supply and $66 \%$ of protein intakes of an average person in the country (Hossain and Deb, 2003; Greenfield and Dowling, 1998; Dey et al., 1996). Rice sector contributes one-half of the agricultural GDP and one-sixth of the national income in Bangladesh (Hossain, 2002). Thus, rice plays a vital role in the livelihood of the people. To be able to meet the world's food demand by 2025 , it is estimated that rice production has to increase globally by $60 \%$ (Fageria, 2007). But 
Rahman et al.

there is little scope to increase the area under rice production with the current practices that involve high production costs of fertilizers and protective chemicals (Sinavagari, 2006). Thus, innovative ways for reducing inputs like water, chemicals, fertilizers and labor while increasing yields on the same piece of land need to be put in place to ensure sustainable rice production (Bouman et al., 2005).

The System of Rice Intensification (SRI), offers an opportunity to improve food security through increased rice productivity by changing the management of plants, soil, water and nutrients while reducing external inputs like fertilizers and herbicides (Berkelaar, 2001; Thakur et al., 2009; Uphoff, 2003; Vermeule, 2009). The system proposes the use of single, very young seedlings with wider spacing, intermittent wetting and drying, use of a mechanical weeder which also aerates the soil, and enhanced soil organic matter (Uphoff and Kassam, 2009). SRI is a technique that is a set of practices and a set of principles rather than as a "technology package" (Uphoff, 2004). SRI is not a technology like the seed of high-yielding varieties or like a chemical fertilizer or insecticide. It is a system for managing plants, soil, water or nutrient together in mutually beneficial ways, creating synergies (Laulanié, 1993). With SRI, management practices control or modify the microenvironment so that existing genetic potentials can be more fully expressed and realized. The most obvious advantage from SRI appears to be the yield increase in farmers' field without any new seeds or chemical and mechanical inputs (Stoop et al., 2002) and that is reported to be from $50 \%$ to $200 \%$ (Uphoff, 2005).

To increase quality yield of rice in Bangladesh it is necessary to improve nutrient management of rice field. Proper utilization of different sources of nutrients in context of crop-soil productivity must be explored for sustaining the productivity. The sources of nutrient for crops are nutrient reserve in soil, organic and inorganic fertilizers. None of the sources are complete and therefore, no one is sufficient to sustain soil fertility and productivity. Combination of organic and chemical fertilizer is being stressed now a day. It established that the application of different fertilizers and manures influence the physical and chemical properties of soil and enhance the biological activities. Application of both chemical and organic fertilizers is needed for the improvement of soil physical properties and quick supply of essential plant nutrients for higher yield as well as to keep the soil physical properties (Davarynejad et al., 2004; Singh and Singh, 2000). Because of these variable information's about the effect of manural status on yield of Boro rice, a detailed study was undertaken to identification of SRI effectiveness in respect of fertilizer management and yield increase.

\section{Materials and Methods}

The experiment was conducted to study the optimum fertilizer and water management in SRI concept for optimum yield in rice during the period from December, 2011 to May, 2012 at the Agronomy field, Sher-e-Bangla Agricultural University, Dhaka-1207, Bangladesh. The soil belongs to Tejgaon Series under Agro-ecological zone of The "Modhupur Tract", AEZ-28. The soil of the site belongs to the general soil type, Shallow Red Brown Terrace Soils under Tejgaon Series. Top soils were clay loam in texture, olive-gray with common fine to medium distinct dark yellowish brown mottles. Soil pH ranged from 6.1-6.5 and had organic matter 1.29\%. The experiment was laid out in a split-plot design with three replications having two factors i.e. Factor-A: Three type of water regime viz. $\mathrm{W}_{1}=$ Waterlogged (The level of water in each pot was maintained at about $5 \mathrm{~cm}$ above the soil surface throughout the growing period of the crop until near maturity. Irrigation was scheduled at 4 day intervals starting 7 days after transplanting (DAT). Plots were equipped with drainage irrigation system for continuous flood irrigation (up to 5-6 cm depth) throughout the rice-growing season.), $\mathrm{W}_{2}=$ Saturated (water was applied just to 
Yield of Boro Rice Under System of Rice Intensification

saturate the soil (without flood) throughout the growing period of the crop. For maintaining field capacity, periodic irrigation was applied to maintain the soil at about field capacity from transplanting to maturity. Plots were watered every day in the morning by sprinkling.), $\mathrm{W}_{3}=$ Alternate wet and dry (Alternate wet and dry (AWD) is a water management system where rice fields are not kept continuously submerged but are allowed to dry intermittently during the rice growing stage. Intermittent irrigation was scheduled at 10 day intervals starting 7 days after transplanting (DAT) up to maturity. Water level was maintained about $5 \mathrm{~cm}$ above during the wetting period. Water level was dried in such a level that hairline cracks were develop in the field) and Factor-B: six type of fertilizer management viz. $F_{1}=$ Cowdung $100 \%$ (The selected plots were applied with $10000 \mathrm{~kg} \mathrm{ha}^{-1}$ cowdung. The entire amount of cow dung was applied as basal dose at final land preparation.), $F_{2}=$ Compost $100 \%$ (The $10000 \mathrm{~kg} \mathrm{ha}^{-1}$ compost was applied to the selected plots. The entire amount of compost was also applied as basal dose at final land preparation.), $\mathrm{F}_{3}=$ Chemical fertilizer $100 \%$. The experimental plots were fertilized with 195,95 , 65,70 and $10 \mathrm{~kg} \mathrm{ha}^{-1}$ Urea, TSP, MOP, Gypsum and zinc sulphate, respectively. The entire amounts of triple super phosphate, muriate of potash, gypsum and zinc sulphate were applied as basal dose at final land preparation. Urea was top-dressed in four equal installments. First installment was done after seedling recovery and the rest three installments were done at 20 days interval.), $\mathrm{F}_{4}=$ Chemical fertilizer $50 \%+$ cowdung $25 \%+$ compost $25 \%, \mathrm{~F}_{5}=$ Chemical fertilizer $50 \%+$ cowdung $50 \%, \mathrm{~F}_{6}=$ Chemical fertilizer $50 \%+$ compost $50 \%$. BRRI dhan 45 was used as plant material. Seeds were sown in the portable trays on December 28, 2011. The 12 days old seedlings were uprooted from the trays and transplanted on January 10, 2012. The trays were brought to the main field and seedlings were planted in the prepared plot just after uprooting. The spacing was maintained plant to plant $30 \mathrm{~cm}$ and row to row $30 \mathrm{~cm}$. Data on yield attributes was determined from randomly selected five hills of each plot and grain and straw yields were recorded from the inner rows leaving border lines at harvest stage. $6 \mathrm{~m}^{2}$ areas crop of each plot were separately harvested, bundled, tagged and then brought to the threshing floor for recording grain and straw yield. Threshing was done using pedal thresher. The grains were cleaned and sun dried to a moisture content of $14 \%$. Straw was also sun dried properly. Finally grain and straw yields were determined and converted to ton ha ${ }^{-1}$. All the collected data were analyzed following the analysis of variance (ANOVA) technique using IRRISTAT package and the mean difference were adjusted by LSD technique (Gomez and Gomez, 1984).

\section{Results and Discussion}

The number of effective tillers hill ${ }^{-1}$, filled grains panicle ${ }^{-1}$, 1000-grain weight and harvest index were not significantly influenced by water regime. The numerical maximum number of effective tillers hill-1 ${ }^{-1}$ (30.50) was given by $\mathrm{W}_{2}$ condition, filled grains panicle ${ }^{-1}$ (75.61) in $\mathrm{W}_{1}$ condition, 1000-grains weight (22.63g) in $\mathrm{W}_{2}$ and harvest index (46.16\%) in $\mathrm{W}_{2}$ condition (Table 1). Stoop (2005) found higher harvest index in SRI comparing the conventional method, though, Barison (2003) found no difference for the same. The total number of grains panicle ${ }^{-1}$ was significantly influenced by water regime. The highest number of grains panicle ${ }^{-1}$ (96.22) was obtained from $\mathrm{W}_{1}$ condition statistically similar with $\mathrm{W}_{2}$ condition and the lowest number of grains panicle 1 (82.98) was obtained from $\mathrm{W}_{3}$ condition. This result was similar with Bouman, et al. (2005). The highest grain yield $\left(5.74 \mathrm{tha}^{-1}\right)$ was obtained from the $\mathrm{W}_{1}$ condition that was statistically similar with $\mathrm{W}_{2}$ condition and the lowest $\left(4.36 \mathrm{t} \mathrm{ha}^{-1}\right)$ was from $\mathrm{W}_{3}$ condition. Bouman and Tuong (2001) suggested that there is a reduction in the grain yield in alternate wetting and drying when compared with rice grown with standing water. The highest straw yield $\left(6.74 \mathrm{t} \mathrm{ha}^{-1}\right)$ was obtained from the $\mathrm{W}_{1}$ condition that was statistically similar with $\mathrm{W}_{2}$ condition and the lowest 
Rahman et al.

$\left(5.22 \mathrm{t} \mathrm{ha}^{-1}\right)$ was from $\mathrm{W}_{3}$ condition. The highest biological yield $\left(12.48 \mathrm{t} \mathrm{ha}^{-1}\right)$ was found from $\mathrm{W}_{1}$ condition and the lowest biological yield $\left(9.59 \mathrm{t} \mathrm{ha}^{-1}\right)$ was found from $\mathrm{W}_{3}$ condition.

Table 1. Influence of water regime on different yield contributing characters of Boro rice transplanted in SRI

\begin{tabular}{l|c|c|c|c|c|c|c|c}
\hline Treatments & $\begin{array}{c}\text { Effective } \\
\text { tiller no. } \\
\text { hill-1 }\end{array}$ & $\begin{array}{c}\text { Total } \\
\text { grains } \\
\text { panicle } \\
(\text { No. }\end{array}$ & $\begin{array}{c}\text { Filled } \\
\text { grains } \\
\text { panicle } \\
(\text { No. })\end{array}$ & $\begin{array}{c}1000- \\
\text { grain } \\
\text { weight } \\
(\mathrm{g})\end{array}$ & $\begin{array}{c}\text { Grain } \\
\text { yield } \\
\left(\mathrm{t} \mathrm{ha}^{-1}\right)\end{array}$ & $\begin{array}{c}\text { Straw } \\
\text { yield } \\
\left(\mathrm{t} \mathrm{ha}^{-1}\right)\end{array}$ & $\begin{array}{c}\text { Biological } \\
\text { yield } \\
\left(\mathrm{t} \mathrm{ha}^{-1}\right)\end{array}$ & $\begin{array}{c}\text { Harvest } \\
\text { index } \\
(\%)\end{array}$ \\
\hline $\mathrm{W}_{1}$ & 26.92 & $96.22 \mathrm{a}$ & 75.61 & 22.58 & $5.74 \mathrm{a}$ & $6.74 \mathrm{a}$ & $12.48 \mathrm{a}$ & 46.02 \\
$\mathrm{~W}_{2}$ & 30.50 & $95.82 \mathrm{a}$ & 74.70 & 22.63 & $5.69 \mathrm{a}$ & $6.65 \mathrm{a}$ & $12.33 \mathrm{a}$ & 46.16 \\
$\mathrm{~W}_{3}$ & 28.20 & $82.98 \mathrm{~b}$ & 71.76 & 22.18 & $4.36 \mathrm{~b}$ & $5.22 \mathrm{~b}$ & $9.59 \mathrm{~b}$ & 45.55 \\
\hline $\mathrm{LSD}_{(0.05)}$ & $\mathrm{NS}$ & 10.706 & $\mathrm{NS}$ & $\mathrm{NS}$ & 0.383 & 0.458 & 0.819 & $\mathrm{NS}$ \\
$\mathrm{CV}(\%)$ & 16.48 & 12.59 & 6.24 & 5.36 & 7.86 & 7.98 & 7.71 & 2.04 \\
\hline
\end{tabular}

$\mathrm{W}_{1}=$ Waterlogged, $\mathrm{W}_{2}=$ Saturated, $\mathrm{W}_{3}=$ Alternate wet and dry and NS= Not Significant.

Manural status significantly influenced the number of effective tillers hill ${ }^{-1}$. The highest number of effective tillers hill ${ }^{-1}$ (33.71) was obtained from $F_{2}$ which was statistically similar with $F_{1}$. The lowest effective tillers hill-1 (25.42) was obtained from $\mathrm{F}_{6}$ that was statistically similar with $\mathrm{F}_{3}$ and $F_{5}$. Hossaen et al. (2011) conducted an experiment to evaluate the efficacy of different organic manure and inorganic fertilizer and recorded maximum number of effective tillers hill ${ }^{-1}$ from the treatment of $70 \%$ NPKS $+2.4 \mathrm{t}_{\text {manure }} \mathrm{ha}^{-1}$. The highest number of total grains panicle ${ }^{-1}$ (107.98) was obtained from $\mathrm{F}_{3}$ and the lowest number of grains panicle-1 (86.80) was recorded from $F_{1}$ that was similar to $F_{2}$. The highest number of filled grains panicle ${ }^{-1}(84.78)$ was obtained from $F_{1}$ that similar to the $F_{3}$ and $F_{4}$ and the lowest number of filled grains panicle ${ }^{-1}$ (65.51) was obtained from $\mathrm{F}_{5}$ (Table 2). Basunia (2005) reported that frequent combined application of cowdung plus inorganic fertilizer rates increased production from successive filled grains panicle $e^{-1}$. There was no significant effect among the different manural status in respect of weight of 1000-grains though the numerically maximum 1000-grains weight $(22.73 \mathrm{~g})$ was observed at $\mathrm{F}_{2}$ and the minimum (22.18) in $\mathrm{F}_{3}$. Manural status has significant effect on grain yield. $\mathrm{F}_{4}$ produced significantly the highest grain yield $\left(5.81 \mathrm{t} \mathrm{ha}^{-1}\right)$ that was statistically similar to $F_{3}$. The lowest $\left(4.71 \mathrm{t} \mathrm{ha}{ }^{-1}\right)$ grain yield was from $F_{2}$ that was similar with $F_{1}$. Das (2003) earlier stated that soils with high fertility influence the grain yield.

Table 2. Influence of manural status on different yield contributing characters of Boro rice transplanted in SRI

\begin{tabular}{l|c|c|c|c|c|c|c|c}
\hline Treatments & $\begin{array}{c}\text { Effective } \\
\text { tiller no. } \\
\text { hill-1 }\end{array}$ & $\begin{array}{c}\text { Total } \\
\text { grains } \\
\text { panicle } \\
\text { (No.) }\end{array}$ & $\begin{array}{c}\text { Filled } \\
\text { grains } \\
\text { panicle-1 } \\
(\text { No.) }\end{array}$ & $\begin{array}{c}1000- \\
\text { grain } \\
\text { weight } \\
(\mathrm{g})\end{array}$ & $\begin{array}{c}\text { Grain } \\
\text { yield } \\
\left(\mathrm{t} \mathrm{ha}^{-1}\right)\end{array}$ & $\begin{array}{c}\text { Straw } \\
\text { yield } \\
\left(\mathrm{t} \mathrm{ha}^{-1}\right)\end{array}$ & $\begin{array}{c}\text { Biological } \\
\text { yield } \\
\left(\mathrm{t} \mathrm{ha}^{-1}\right)\end{array}$ & $\begin{array}{c}\text { Harvest } \\
\text { index } \\
(\%)\end{array}$ \\
\hline $\mathrm{F}_{1}$ & $30.24 \mathrm{ab}$ & $80.02 \mathrm{c}$ & $84.78 \mathrm{a}$ & 22.44 & $4.72 \mathrm{c}$ & $5.43 \mathrm{c}$ & $10.13 \mathrm{c}$ & $46.28 \mathrm{ab}$ \\
$\mathrm{F}_{2}$ & $33.71 \mathrm{a}$ & $86.80 \mathrm{bc}$ & $72.80 \mathrm{bc}$ & 22.73 & $4.71 \mathrm{c}$ & $5.43 \mathrm{c}$ & $10.16 \mathrm{c}$ & $46.37 \mathrm{ab}$ \\
$\mathrm{F}_{3}$ & $26.44 \mathrm{~cd}$ & $107.98 \mathrm{a}$ & $74.27 \mathrm{abc}$ & 22.18 & $5.77 \mathrm{a}$ & $6.80 \mathrm{a}$ & $12.56 \mathrm{a}$ & $45.92 \mathrm{ab}$ \\
$\mathrm{F}_{4}$ & $29.98 \mathrm{bc}$ & $95.73 \mathrm{~b}$ & $79.84 \mathrm{ab}$ & 22.51 & $5.81 \mathrm{a}$ & $6.64 \mathrm{ab}$ & $12.48 \mathrm{a}$ & $46.78 \mathrm{a}$ \\
$\mathrm{F}_{5}$ & $25.44 \mathrm{~d}$ & $91.00 \mathrm{~b}$ & $65.51 \mathrm{c}$ & 22.38 & $5.36 \mathrm{~b}$ & $6.26 \mathrm{~b}$ & $11.64 \mathrm{~b}$ & $46.04 \mathrm{ab}$ \\
$\mathrm{F}_{6}$ & $25.42 \mathrm{~d}$ & $89.91 \mathrm{~b}$ & $66.93 \mathrm{c}$ & 22.53 & $5.21 \mathrm{~b}$ & $6.66 \mathrm{ab}$ & $11.84 \mathrm{~b}$ & $44.06 \mathrm{~b}$ \\
\hline $\mathrm{LSD}_{(0.05)}$ & 3.563 & 9.392 & 11.489 & $\mathrm{NS}$ & 0.355 & 0.463 & 0.578 & 2.597 \\
$\mathrm{CV}(\%)$ & 13.70 & 10.62 & 16.00 & 3.00 & 7.01 & 7.77 & 5.23 & 5.88 \\
\hline
\end{tabular}

$\mathrm{F}_{1}=$ Cowdung $(100 \%), \mathrm{F}_{2}=$ Compost $(100 \%), \mathrm{F}_{3}=$ Chemical fertilizer $(100 \%), \mathrm{F}_{4}=$ Chemical fertilizer $(50 \%)+$ Cowdung $(25 \%)+$ Compost $(25 \%), F_{5}=$ Chemical fertilizer $(50 \%)+$ Cowdung $(50 \%), F_{6}=$ Chemical fertilizer $(50 \%)+$ compost (50\%) and NS= Not significant 
Yield of Boro Rice Under System of Rice Intensification

Das (2003) found that yield of boro rice was significantly influenced by organic matter, cation exchange capacity, nitrogen, phosphorus and potassium. The highest straw yield $\left(6.80 \mathrm{t} \mathrm{ha}^{-1}\right)$ was obtained from $F_{3}$ that was similar with $F_{4}$ and $F_{6}$. The probable reasons of increased straw yield in the $\mathrm{F}_{3}$ might be due to higher total number of tillers $\mathrm{m}^{-2}$ and taller plants. The lowest straw yield $\left(5.43 \mathrm{t} \mathrm{ha}{ }^{-1}\right)$ was obtained from $F_{1}$ and $F_{2}$. Hossain and Deb (2003) was found lowest straw yield in conventional method than SRI for BRRI dhan32 variety. The highest biological yield $\left(12.56 \mathrm{t} \mathrm{ha}^{-1}\right)$ was found from $\mathrm{F}_{3}$ which was similar with $\mathrm{F}_{4}$. The lowest biological yield $\left(10.13 \mathrm{t} \mathrm{ha}^{-1}\right)$ was found from $\mathrm{F}_{1}$ that was statistically similar with $\mathrm{F}_{2}$. The highest harvest index $(46.78 \%)$ was found from chemical $\mathrm{F}_{4}$ that was similar with all other treatments and the lowest $(44.06 \%)$ was from $\mathrm{F}_{6}$.

The number of effective tillers hill ${ }^{-1}$ was significantly influenced by the interaction effect of water regime and manural status. The maximum number of effective tillers hill ${ }^{-1}(28.80)$ was obtained from $\mathrm{W}_{1} \mathrm{~F}_{4}$ which was similar with $\mathrm{W}_{1} \mathrm{~F}_{1}, \mathrm{~W}_{1} \mathrm{~F}_{2}, \mathrm{~W}_{2} \mathrm{~F}_{2}, \mathrm{~W}_{2} \mathrm{~F}_{5}, \mathrm{~W}_{2} \mathrm{~F}_{6}, \mathrm{~W}_{3} \mathrm{~F}_{1}$ and $\mathrm{W}_{3} \mathrm{~F}_{2}$. The lowest number of effective tillers hill-1 ${ }^{-1}$ (20.53) was obtained from $\mathrm{W}_{1} \mathrm{~F}_{6}$ (Table 3).

Table 3. Interaction effect of water regime and manural status on different yield contributing characters of Boro rice transplanted in SRI

\begin{tabular}{|c|c|c|c|c|c|c|c|c|}
\hline Treatments & $\begin{array}{c}\text { Effective } \\
\text { tiller no. } \\
\text { hill-1 }^{-1}\end{array}$ & $\begin{array}{c}\text { Total grains } \\
\text { panicle }{ }^{-1} \\
\text { (No.) }\end{array}$ & $\begin{array}{c}\text { Filled } \\
\text { grains } \\
\text { panicle }{ }^{-1} \\
\text { (No.) }\end{array}$ & $\begin{array}{l}\text { 1000- } \\
\text { grain } \\
\text { weight } \\
\text { (g) }\end{array}$ & $\begin{array}{c}\text { Grain } \\
\text { yield } \\
\left(\mathrm{t} \mathrm{ha}^{-1}\right)\end{array}$ & $\begin{array}{c}\text { Straw } \\
\text { yield } \\
\left(\mathrm{t} \mathrm{ha}^{-1}\right)\end{array}$ & $\begin{array}{c}\text { Biological } \\
\text { yield } \\
\left(\mathrm{t} \mathrm{ha}^{-1}\right)\end{array}$ & $\begin{array}{c}\text { Harvest } \\
\text { index } \\
(\%)\end{array}$ \\
\hline $\mathrm{W}_{1} \mathrm{~F}_{1}$ & $30.47 a-d$ & 96.53b-e & $88.00 \mathrm{a}$ & $22.73 a b$ & $5.77 \mathrm{de}$ & $6.45 c-e$ & $12.20 c-d$ & $47.17 a$ \\
\hline $\mathrm{W}_{1} \mathrm{~F}_{2}$ & $34.67 a$ & $93.80 \mathrm{~b}-\mathrm{g}$ & $66.27 b c$ & $22.80 \mathrm{ab}$ & 4.99f-h & $5.65 e-h$ & $10.67 e-h$ & $46.89 a$ \\
\hline $\mathrm{W}_{1} \mathrm{~F}_{3}$ & $25.27 \mathrm{~d}-\mathrm{g}$ & $115.60 \mathrm{a}$ & $80.67 a-c$ & 22.23ab & $6.89 a$ & $6.83 \mathrm{~b}-\mathrm{d}$ & $12.83 \mathrm{bc}$ & $46.79 a$ \\
\hline $\mathrm{W}_{1} \mathrm{~F}_{4}$ & 28.80a-e & $103.20 \mathrm{a}-\mathrm{c}$ & $85.60 \mathrm{ab}$ & $22.57 \mathrm{ab}$ & $6.00 \mathrm{~cd}$ & 7.16a-c & $13.17 b c$ & $45.59 a$ \\
\hline $\mathrm{W}_{1} \mathrm{~F}_{5}$ & $21.80 \mathrm{fg}$ & 95.93b-f & $67.20 b c$ & 22.73ab & $6.46 a-c$ & $6.81 \mathrm{~b}-\mathrm{d}$ & $13.27 b$ & $48.71 a$ \\
\hline $\mathrm{W}_{1} \mathrm{~F}_{6}$ & $20.53 \mathrm{~g}$ & 76.47hi & $65.93 b c$ & 22.40ab & $5.22 \mathrm{e}-\mathrm{g}$ & 7.53ab & $12.73 b c$ & $40.95 a$ \\
\hline $\mathrm{W}_{2} \mathrm{~F}_{1}$ & 28.20b-e & 79.80f-i & 82.73ab & 22.50ab & $4.69 \mathrm{~g}-\mathrm{i}$ & $5.62 f-h$ & $10.57 f-h$ & $46.90 a$ \\
\hline $\mathrm{W}_{2} \mathrm{~F}_{2}$ & 33.53ab & $88.00 \mathrm{c}-\mathrm{h}$ & 73.93a-c & $22.87 a$ & 4.99f-h & 5.73efh & $10.90 e-g$ & $47.61 a$ \\
\hline $\mathrm{W}_{2} \mathrm{~F}_{3}$ & 28.20b-e & $108.53 \mathrm{ab}$ & $70.53 a-c$ & 22.60ab & $6.21 \mathrm{~b}-\mathrm{d}$ & 7.43ab & $13.63 \mathrm{ab}$ & $45.46 a$ \\
\hline $\mathrm{W}_{2} \mathrm{~F}_{4}$ & 33.33ab & $101.67 a-c$ & 85.33ab & 22.73ab & $6.80 \mathrm{ab}$ & 7.71a & $14.53 a$ & $46.85 a$ \\
\hline $\mathrm{W}_{2} \mathrm{~F}_{5}$ & 30.27a-e & $88.53 c-h$ & $68.27 \mathrm{a}-\mathrm{c}$ & 22.27ab & $5.18 c-g$ & $6.39 c-f$ & 11.60de & $44.77 \mathrm{ab}$ \\
\hline $\mathrm{W}_{2} \mathrm{~F}_{6}$ & 29.47a-e & $108.40 \mathrm{ab}$ & $67.40 b c$ & $22.83 \mathrm{ab}$ & $5.80 \mathrm{c}-e$ & 7.00a-c & $12.77 b c$ & $45.35 \mathrm{ab}$ \\
\hline $\mathrm{W}_{3} \mathrm{~F}_{1}$ & $32.07 \mathrm{a}-\mathrm{c}$ & $63.73 \mathrm{i}$ & $83.60 \mathrm{ab}$ & $22.10 \mathrm{ab}$ & $3.42 \mathrm{k}$ & $4.20 \mathrm{i}$ & $7.63 \mathrm{j}$ & $44.77 \mathrm{ab}$ \\
\hline $\mathrm{W}_{3} \mathrm{~F}_{2}$ & 32.93ab & $78.60 \mathrm{~g}-\mathrm{i}$ & $78.20 \mathrm{a}-\mathrm{c}$ & $22.53 \mathrm{ab}$ & $3.95 \mathrm{jk}$ & 4.91hi & $8.90 \mathrm{i}$ & 44.60ab \\
\hline $\mathrm{W}_{3} \mathrm{~F}_{3}$ & $25.87 \mathrm{~d}-\mathrm{g}$ & $99.80 \mathrm{~b}-\mathrm{d}$ & $71.60 \mathrm{a}-\mathrm{c}$ & $21.70 \mathrm{~b}$ & $5.55 \mathrm{~d}-\mathrm{f}$ & $6.13 \mathrm{~d}-\mathrm{f}$ & 11.20de & $45.49 a$ \\
\hline $\mathrm{W}_{3} \mathrm{~F}_{4}$ & $27.80 b-f$ & $82.33 e-h$ & $68.60 \mathrm{a}-\mathrm{c}$ & 22.23ab & $4.18 \mathrm{ij}$ & $5.05 \mathrm{gh}$ & 9.73hi & $47.92 \mathrm{a}$ \\
\hline $\mathrm{W}_{3} \mathrm{~F}_{5}$ & $24.27 e-g$ & $88.53 c-h$ & $61.07 c$ & $22.13 \mathrm{ab}$ & $4.45 \mathrm{~h}-\mathrm{j}$ & 5.59f-h & $10.07 \mathrm{gh}$ & $44.63 \mathrm{ab}$ \\
\hline $\mathrm{W}_{3} \mathrm{~F}_{6}$ & $26.27 \mathrm{c}-\mathrm{g}$ & $84.87 \mathrm{~d}-\mathrm{g}$ & $67.47 \mathrm{bc}$ & $22.37 \mathrm{ab}$ & $4.61 \mathrm{~g}-\mathrm{j}$ & $5.45 f-h$ & $10.03 \mathrm{gh}$ & $45.87 a$ \\
\hline $\operatorname{LSD}_{(0.05)}$ & 6.171 & 16.268 & 19.899 & 1.139 & 0.615 & 0.803 & 1.001 & 4.498 \\
\hline CV $(\%)$ & 12.97 & 10.62 & 16.12 & 3.04 & 7.01 & 7.77 & 5.23 & 5.88 \\
\hline
\end{tabular}

$\mathrm{W}_{1}=$ Waterlogged, $\mathrm{W}_{2}=$ Saturated, $\mathrm{W}_{3}=$ Alternate wet and dry, $\mathrm{F}_{1}=$ Cowdung $(100 \%), \mathrm{F}_{2}=$ Compost $(100 \%)$, $\mathrm{F}_{3}=\mathrm{Chemical} \mathrm{fertilizer}$ $(100 \%), F_{4}=$ Chemical fertilizer $(50 \%)+$ Cowdung $(25 \%)+$ Compost $(25 \%), F_{5}=$ Chemical fertilizer $(50 \%)+$ Cowdung $(50 \%)$ and $\mathrm{F}_{6}=$ Chemical fertilizer $(50 \%)+$ compost $(50 \%)$

The highest (115.60) number of grains panicle $e^{-1}$ was obtained from $W_{1} F_{3}$ statistically similar with $\mathrm{W}_{1} \mathrm{~F}_{4}, \mathrm{~W}_{2} \mathrm{~F}_{3}, \mathrm{~W}_{2} \mathrm{~F}_{2}$ and $\mathrm{W}_{2} \mathrm{~F}_{6}$. The lowest (63.73) number of grains panicle ${ }^{-1}$ was obtained from $\mathrm{W}_{3} \mathrm{~F}_{1}$ which was similar with $\mathrm{W}_{1} \mathrm{~F}_{6}, \mathrm{~W}_{2} \mathrm{~F}_{1}$ and $\mathrm{W}_{3} \mathrm{~F}_{2}$. The highest number of filled grains panicle 1 (88.00) was obtained from the $\mathrm{W}_{1} \mathrm{~F}_{1}$ followed by $\mathrm{W}_{2} \mathrm{~F}_{3}, \mathrm{~W}_{2} \mathrm{~F}_{2}, \mathrm{~W}_{1} \mathrm{~F}_{1}, \mathrm{~W}_{1} \mathrm{~F}_{2}, \mathrm{~W}_{1} \mathrm{~F}_{3}, \mathrm{~W}_{1} \mathrm{~F}_{4}$, $\mathrm{W}_{1} \mathrm{~F}_{5}, \mathrm{~W}_{3} \mathrm{~F}_{1}, \mathrm{~W}_{3} \mathrm{~F}_{2}, \mathrm{~W}_{3} \mathrm{~F}_{3}$ and $\mathrm{W}_{3} \mathrm{~F}_{4}$. The lowest number of filled grains panicle ${ }^{-1}$ (61.07) was obtained from $\mathrm{W}_{3} \mathrm{~F}_{5}$. The highest weight of 1000-grains $(22.87 \mathrm{~g})$ was obtained from $\mathrm{W}_{2} \mathrm{~F}_{2}$ 
which was similar with all other interaction effect of water regime and manural status except $\mathrm{W}_{3} \mathrm{~F}_{3}$. The lowest weight of 1000 -grains $(21.70 \mathrm{~g})$ was obtained from $\mathrm{W}_{3} \mathrm{~F}_{3}$ which was similar to the all other interaction effect of water regime and manural status except $\mathrm{W}_{2} \mathrm{~F}_{2}$. The highest grain yield was observed in $\mathrm{W}_{2} \mathrm{~F}_{4}\left(6.80 \mathrm{t} \mathrm{ha}^{-1}\right)$ which was similar with $\mathrm{W}_{2} \mathrm{~F}_{3}$ and $\mathrm{W}_{1} \mathrm{~F}_{5}$. The lowest yield $\left(3.42 \mathrm{t} \mathrm{ha}^{-1}\right)$ was observed in $\mathrm{W}_{3} \mathrm{~F}_{1}$ that similar with $\mathrm{W}_{3} \mathrm{~F}_{2}$. The highest straw yield (7.71t ha- ${ }^{-1}$ ) was recorded in $\mathrm{W}_{2} \mathrm{~F}_{4}$ similar with $\mathrm{W}_{1} \mathrm{~F}_{4}, \mathrm{~W}_{1} \mathrm{~F}_{6}, \mathrm{~W}_{2} \mathrm{~F}_{3}$ and $\mathrm{W}_{2} \mathrm{~F}_{6}$. The lowest straw yield $\left(4.20 \mathrm{t} \mathrm{ha}^{-1}\right)$ was found in $\mathrm{W}_{3} \mathrm{~F}_{1}$ which was statistically identical with $\mathrm{W}_{3} \mathrm{~F}_{2}$. Akbar (2004) found highest straw yield in the combination of inbred variety and 15 day old seedlings. The highest biological yield (14.53 $\left.\mathrm{t} \mathrm{ha}^{-1}\right)$ was recorded in $\mathrm{W}_{2} \mathrm{~F}_{4}$ similar with $\mathrm{W}_{2} \mathrm{~F}_{3}$. The lowest biological yield (7.63 t ha-1) was found in $\mathrm{W}_{3} \mathrm{~F}_{1}$. Bouman and Toung (2001) found highest biological yield in combination of the chemical fertilizer and saturated condition. The highest harvest index (48.71\%) was recorded in $\mathrm{W}_{1} \mathrm{~F}_{5}$ that followed by all other treatments. The lowest harvest index (44.60\%) was found in $\mathrm{W}_{3} \mathrm{~F}_{2}$.

\section{Conclusion}

Based on the results of the present study it can be concluded that the highest yield was observed in waterlogged condition and that was statistically similar with saturated condition. The crops with chemical fertilizer 50\% + cow dung 25\% + compost $25 \%$ showed the higher yield that is similar to chemical fertilizer 100\% but more friendly for the environment than chemical fertilizer $100 \%$.

\section{Acknowledgement}

The authors are grateful to the Bangladesh Academy of Sciences for the financial support to conduct the study.

\section{References}

Akbar, M. K. 2004. Response of hybrid and inbred rice varieties to different seedlings ages under system of rice intensification in transplant aman season. M. S. Thesis. Dept. Agron., BAU, Mymensingh.

Barison, J. 2003. Nutrient use efficiency and nutrient uptake in conventional and intensive (SRI) rice cultivation systems in Madagascar. Near final draft of Master's thesis, Department of Crop and Soil Sciences, Cornell University, Ithaca, NY. [http://ciifad.cornell.edu/sri/theses/madgjoelithesis.pdf].

Basunia, M. N. 2005. Influence of inorganic fertilizer and cowdung on the growth yield and quality of Binadhan-5. MS Thesis. Department of Agricultural Chemistry. Bangladesh Agricultural University, Mymensingh.

Berkelaar, D. 2001. SRI, the System of Rice Intensification: Less can be more. ECHO Develop. Notes. 10: 1-7.

Bouman, B. A., S. Peng, A. R. Castaneda and R. M. Visperas. 2005. Yield and water use of irrigated tropical aerobic rice systems Agric. Water Mng. 74: 87-105.

Bouman, B. A. M. and T. P. Toung. 2001. Field Water Management to Save Water and increase its productivity in irrigated rice. Agric. Water Mang. 49: 11-30. 
Yield of Boro Rice Under System of Rice Intensification

Das, L. 2003. Verification and refinement of the System of Rice Intensification in selected areas of Bangladesh. Trial Monitoring Report. SAEF Development Group. [http://ciifad.cornell.edu/sri/countries/bangladesh/bangpetfrep.pdf].

Davarynejad, G. H., G. H. Haghnia and A. Lakzian. 2004. Effect of municipal compost in combination with chemical fertilizers and manure on growth and yield of wheat. Agril. Sci. Technol. 18(1): 101-108.

Dey, M. M., M. N. Miah,, B. A. A. Mustafi and M. Hossain. 1996. Rice production constraints in Bangladesh: Implication for further research priorities. In: Rice Research in Asia: Progress and Priorities. CAB International and IRRI Phillipines.

Fageria, N. K. 2007. Yield physiology of rice. J. Plant Nutr. 30: 843-879.

FAO (Food and Agriculture Organization). 2010. World food situation, the FAO food price index. [www.fao.org/worldfoodsituation/en/689].

Gomez, K. A. and A. A. Gomez. 1984. Statistical Procedures for Agricultural Research. 2 ${ }^{\text {nd }}$ Edn. John Wiley and Sons. New York. Chichester, Brisbane, Toronto, Singapore.p.680.

Greenfield, S. M. and N. G. Dowling. 1998. Introduction and Overview. In: Sustainability of Rice in the Global Food System. N. G. Dowling, S. M. Greenfield and K. S. Fisher, (eds.).

Hossaen, M. A., A. T. M., Shamsuddoha, A. K. Paul, M. S. I. Bhuiyan and A. S. M. Zobaer. 2011. Efficacy of different organic manures and inorganic fertilizer on the yield and yield attributes of boro rice. The Agriculturists. 9(1\&2): 117-125.

Hossain, M. and U. K. Deb. 2003. Liberalization of rice sector: Can Bangladesh withstand regional competition? Poster paper presented at PETRRA communication fair 2003 held at hotel Sheraton, Dhaka on Aug. 10-11.

Hossain, M. Z. 2002. Performance of BRRI dhan32 in the SRI and conventional methods and their technology mixes. M. S. Thesis. Dept. of Agron., BAU, Mymensingh. pp.28-71.

Laulanie, H. 1993. Le systeme de riziculture intensive malgache. Tropicultura (Brussels). 11: 110114.

Mishra, A. 2009. System of rice intensification (SRI): A quest for interactive science to mitigate the climate change vulnerability. Asian Institute of Technology, Agricultural systems and Engineering; School of Environment, Bangkok, Thailand. IOP Conf. Series: Earth Environ. Sci. 6(24): 20-28.

Sinavagari, P. 2006. Traditional and SRI methods of paddy cultivation: a comparative economic analysis. Master of Science thesis submitted to the University of Agricultural Sciences, Department of agricultural economics, Dharwad-580005.

Singh, C. P. J. and S. S. Singh. 2000. Studies on the growth and yield parameters of wheat (Triticum aestivum L.) to urea and sludge based compost application. Madras Agril. J. 87(10-12): 727728.

Stoop, W. A., N. Uphoff and A. Kassam. 2002. A review of agricultural research issues raised by the System of Rice Intensification (SRI) from Madagascar: Opportunities for improving farming systems for resource-poor farmers. Agril. Sys. 71(3): 249-274.

Stoop, W. A. 2005. The System of Rice Intensification (SRI): Results from exploratory field research in Ivory Coast, Research needs and prospects for adaptation to diverse production systems of resource-poor farmers. West African Rice Development Association (WARDA), 01 BP 2551, Bouaké, Ivory Coast. [http://ciifad.cornell.edu/sri/stoopwarda05.pdf]. 
Rahman et al.

Thakur, A. K., S. Rath, D. U. Patil and A. Kumar. 2011. Effects on rice plant morphology and physiology of water and associated management practices of the System of Rice Intensification (SRI) and their implications for crop performance. Paddy Water Env. 9: 1324.

Thakur, A. K., N. Uphoff and E. Antony. 2009. An assessment of physiological effects of System of Rice Intensification (SRI) practices compared with recommended rice cultivation practices in India. J. Expt. Agric. 46(1): 77-98.

Uphoff, N. 2003. Higher yields with fewer external inputs? The system of rice intensification and potential contributions to agricultural sustainability. Intl. J. Agric. Sust. 1: 38-50.

Uphoff, N. 2004. What is being learned about system of rice intensification in china and other countries? Agroecological Perspectives for Sustainable Development Seminar Series. Cornell University. 15 Sept.

Uphoff, N. 2005. Agroecologically sound agricultural systems: Can they provide for the world's growing populations? The global food \& product chain-dynamics, innovations, conflicts, strategies. Deutscher Tropentag, Oct. 11-13. Hohenheim. [www.tropentag.de/2005/ abstracts/links/uphoff_sdkbqnqq.pdf].

Uphoff, N. and A. Kassam. 2009. Case study: System of Rice Intensification (SRI), in agricultural technologies for developing countries. Final report. Annex 3. European Technology Assessment Group, Karlsruhe, Germany.

Vermeule, M. 2009. More from less, from less to more. Scaling up: Dissemination of a rice cultivation technique. Farming Matters. Amsterfoort, the Netherlands. p.3. 